\title{
PERBEDAAN KEMAMPUAN KONEKSI MATEMATIK DAN BERPIKIR KREATIF DENGAN DISCOVERY LEARNING DAN DIRECT INSTRUCTION
}

\author{
Samuel Juliardi Sinaga \\ Pendidikan Matematika FKIP Universitas HKBP Nommensen \\ e-mail: samuelsinaga856@gmail.com
}

\begin{abstract}
This study was conducted based on low connection mathematical and creative thinking ability of students. The aim of this study was to determine: (1) whether the connection mathematical of students use Discovery Learning is different than Direct Instruction, (2) whether the creative thinking abilities students Discovery Learning is different than Direct Instruction, (3) the student answers use Discovery Learning variatever than Direct Instruction, (4) to responses the students used Discovery Learning very positive. This study is a quasi experimental research. The study population was all students of class VII SMP Swasta Ampera Batang Kuis consisting of three parallel classes. Of all students in grade VII students of two classes selected for the sample. The experimental class were treated Discovery Learning and control class were treated Direct instruction. In this research has developed several learning tools such as lesson plan and student activity sheets. The instrument used to collect data in this study are: (1) test the ability of connection mathematical, (2) test the ability creative thinking of students. The tests were used is in the form of a description. The test has been declared valid and reliable by the reliability coefficient of 0.814 and 0.878 . Descriptive analysis is intended to describe the students' answers.
\end{abstract}

Keywords : Discovery Learning, Direct Instruction, Connection Mathematical, Creative Thinking Ability.

\begin{abstract}
ABSTRAK
Penelitian ini dilakukan berdasarkan rendahnya kemampuan koneksi matematik dan berpikir kreatif siswa.Tujuan dari penelitian ini untuk mengetahui : (1) apakah kemampuan koneksi matematik siswa menggunakan Discovery Learning berbeda dari Direct Instruction, (2) apakah kemampuan berpikir kreatif siswa menggunakan Discovery Learning berbeda dari Direct Instruction, (3) proses jawaban siswa menggunakan Discovery Learning lebih bervariasi dari Direct Instruction, (4) Respon siswa lebih positif menggunakan Discovery Learning. Penelitian ini merupakan penelitian eksperimen semu. Populasi penelitian ini adalah seluruh siswa kelas VII SMP Swasta Ampera Batang Kuis yang terdiri dari 3 kelas paralel. Dari seluruh siswa kelas VII dipilih siswa sebanyak dua kelas sebagai sampel. Kelas eksperimen diberi perlakuan Discovery Learning dan kelas kontrol diberi perlakuan Direct Instruction. Dalam penelitian ini telah dikembangkan beberapa perangkat pembelajaran seperti RPP dan LKS.Instrumen yang digunakan untuk mengumpulkan data dalam penelitian ini yaitu: (1) tes kemampuan koneksi matematik, (2) tes kemampuan berpikir kreatif. Tes yang digunakan adalah berbentuk uraian yang telah dinyatakan valid dan reliable dengan koefisien reliabilitas sebesar 0,814 dan 0,878. Analisis deskriptif ditujukan untuk mendeskripsikan jawaban siswa.
\end{abstract}

Kata Kunci: Discovery Learning, Direct Instruction, Kemampuan Koneksi Matematik, Berpikir Kreatif Siswa.

\section{PENDAHULUAN}

Matematika sebagai suatu disiplin ilmu yang secara jelas mengandalkan proses berpikir dipandang sangat baik untuk diajarkan pada anak didik. Di dalamnya terkandung berbagai aspek yang secara substansial menuntun murid untuk berpikir logis menurut pola dan aturan yang telah tersusun 


\section{SEPREN: Journal of Mathematics Education and Applied}

Vol. 01, No.02, 16-27

secara baku. Sehingga seringkali tujuan utama dari mengajarkan matematika tidak lain untuk membiasakan agar anak didik mampu berpikir logis, kritis, kreatif dan sistematis. Khususnya berpikir kritis dan kreatif, sangat diperlukan bagi kehidupan mereka, agar mereka mampu menyaring informasi, memilih layak atau tidaknya suatu pengetahuan dan mempertanyakan suatu kebenaran. Apalagi pada pembelajaran matematika yang dominan mengandalkan kemampuan daya pikir dan mengaitkan dalam kehidupan nyata, perlu membina kemampuan koneksi dan berpikir siswa agar mampu mengatasi permasalahan pembelajaran matematika tersebut yang materinya cenderung bersifat abstrak dan siswa juga mampu mencapai tujuan dari pembelajaran matematika tersebut.

Adapun tujuan pembelajaran Matematika secara khusus dijabarkan dalam Kemendikbud tahun 2013 tentang Implementasi Kurikulum 2013, matematika diajarkan di sekolah membawa misi yang sangat penting, yaitu mendukung ketercapaian tujuan pendidikan nasional. Secara umum tujuan pendidikan matematika di sekolah yaitu Tujuan yang bersifat formal, menekankan kepada menata penalaran dan membentuk kepribadian peserta didik sedangkan tujuan yang bersifat material menekankan kepada kemampuan memecahkan masalah dan menerapkan matematika.

Secara lebih terinci, tujuan pembelajaran matematika yaitu Melatih cara berpikir dan bernalar dalam menarik kesimpulan, misalnya melalui kegiatan penyelidikan, eksplorasi, eksperimen, menunjukkan kesamaan, perbedaan, konsistensi dan inkonsistensi. (b) Mengembangkan aktivitas kreatif yang melibatkan imajinasi, intuisi, dan penemuan dengan mengembangkan pemikiran divergen, orisinil, rasa ingin tahu, membuat prediksi dan dugaan, serta mencoba-coba. (c) Mengembangkan kemampuan memecahkan masalah. (d) Mengembangkan kemampuan menyampaikan informasi atau mengkomunikasikan gagasan antara lain melalui pembicaraan lisan, grafik, peta, diagram, dalam menjelaskan gagasan tersebut.

Meninjau tujuan pelajaran matematika diatas maka suatu proses pembelajaran matematika haruslah memberikan kesempatan pada siswa untuk dapat melihat dan mengalami sendiri kegunaan matematika dalam kehidupan nyata, serta memberikan kesempatan untuk siswa agar dapat mengkonstruksi sendiri pengetahuan melalui berbagai aktifitas seperti pemecahan masalah, penalaran, berkomunikasi, koneksi, representasi dan berpikir kritis serta kreatif.

Harapannya siswa dapat menguasai konsep dasar matematika secara benar sehingga dapat menerapkannya dalam kehidupan sehari-hari. Lebih jauh pembelajaran matematika diharapkan dapat mengembangkan kemampuan bermatematika dan meningkatkan kemampuan memecahkan masalah. Kemampuan pemecahan masalah merupakan hal yang penting dalam pelajaran matematika untuk dapat melakukan pemecahan masalah dengan baik, maka diperlukan kemampuan koneksi dan berpikir kreatif. Matematika adalah suatu alat untuk mengembangkan cara berpikir, matematika juga sangat diperlukan 


\section{SEPREN: Journal of Mathematics Education and Applied}

Vol. 01, No.02, 16-27

baik untuk kehidupan sehari-hari maupun dalam menghadapi kemajuan ilmu dan teknologi. Sehingga pelajaran matematika perlu diberikan kepada setiap peserta didik sejak Sekolah Dasar (SD), bahkan sejak Taman Kanak-Kanak (TK). Dengan demikian harapan yang ingin dicapai dalam pembelajaran matematika adalah memiliki keterampilan berpikir matematika yang memadai, karena siswa harus dipersiapkan sikap dan mental untuk menghadapi situasi dan kondisi perkembangan globalisasi dunia, teknologi dan informasi di masa depan.

Namun kenyataan menunujukkan bahwa prestasi matematika siswa-siswa Indonesia masih belum memuaskan. Hal ini terlihat dari Hasil studi internasional dalam bidang matematika dan IPA pada Third International Mathematics and Science Study (TIMSS), menunjukan bukti bahwa soal-soal matematika yang memerlukan kemampuan berpikir tingkat tinggi (higher-order thingking), pada umumnya tidak berhasil dijawab dengan benar oleh sampel siswa Indonesia.

Ketidakberhasilan tersebut disebabkan oleh rendahnya kualitas pembelajaran matematika di Indonesia, yang kali ini terlihat pada hasil survei Trends in International Mathematics and Science Study (TIMSS) pada tahun 2011 yang diikuti 42 negara, siswa - siswa indonesia menempati urutan ke 38. Pada studi TIMSS juga terungkap bahwa siswa Indonesia lemah dalam menyelesaikan soal-soal tidak rutin yang berkaitan dengan jastifikasi atau pembuktian, pemecahan masalah yang memerlukan penalaran matematika, menemukan generalisasi atau konjektur, dan menemukan hubungan antara data-data atau fakta yang diberikan. Sedangkan dalam studi PISA, siswa Indonesia lemah dalam menyelesaikan soalsoal yang difokuskan pada mathematics literacy yang ditunjukkan oleh kemampuan siswa dalam menggunakan matematika yang mereka pelajari untuk menyelesaikan persoalan dalam kehidupan seharihari. Hal serupa juga ditunjukkan dengan hasil studi PISA tahun 2012 menempatkan Indonesia pada urutan ke 64 dari 65 negara peserta dengan skor 375, sedangkan skor rata - rata yang harus dicapai adalah 494, dapat dilihat dari jumlah skor yang di dapat bahwa kemampuan matematika siswa Indonesia masih rendah, jauh berbeda dengan negara Singapura yang jauh berada pada posisi ke 2 dengan skor 573.

Dari Pernyataan di atas salah satu aspek yang ditekankan agar kemampuan matematika siswa indonesia dapat meningkat adalah meningkatkan kemampuan koneksi matematik, tingkat koneksi matematik seorang siswa lebih dipengaruhi oleh pengalaman siswa itu sendiri. Kemampuan koneksi matematik juga merupakan salah satu kemampuan yang sangat penting dan harus dikembangkan karena dalam pembelajaran matematika setiap konsep berkaitan satu sama lain dengan konsep lainnya. (Bruner, 1977) menyatakan bahwa anak perlu menyadari bagaimana hubungan antar konsep, karena antara sebuah bahasan dengan bahasan matematika lainnya saling berkaitan. Selanjutnya, Lasmawati (dalam Lestari, 2014) mengungkapkan bahwa melalui koneksi matematik, wawasan siswa akan semakin terbuka terhadap matematika, yang kemudian akan menimbulkan sikap positif terhadap matematika itu sendiri. Melalui 


\section{SEPREN: Journal of Mathematics Education and Applied}

Vol. 01, No.02, 16-27

proses koneksi matematik, konsep pemikiran dan wawasan siswa terhadap matematika akan semakin lebih luas, tidak hanya terfokus pada topik yang sedang dipelajari.

Hal ini berarti kemampuan koneksi matematik seorang siswa dalam belajar diperoleh dari apa yang ia alami dalam pembelajaran tersebut. Selanjutnya, Bruner menyatakan pembelajaran matematika merupakan usaha untuk membantu siswa dalam mengkonstruksi pengetahuan melalui proses, karena mengetahui adalah suatu proses, bukan suatu produk. Hal ini sejalan dengan pendapat Vygotsky yang menyatakan bahwa, konstruksi pengetahuan terjadi melalui proses interaksi sosial bersama orang lain yang lebih mengerti, dapat mengaitkan dan paham akan pengetahuan tersebut. Proses tersebut dimulai dari pengalaman, sehingga siswa harus diberi kesempatan seluas-luasnya untuk mengkonstruksi sendiri pengetahuan yang harus dimilikinya. Dari pendapat tersebut dapat diambil kesimpulan bahwa suatu kemampuan koneksi diperoleh oleh siswa melalui suatu rangkaian proses yang dilalui oleh siswa saat belajar dan interaksi yang terjadi saat belajar bersama orang lain, sehingga siswa dapat membentuk pengetahuan dan mampu mengkoneksikan pengetahuan tersebut dari apa yang dialaminya.

Kemampuan koneksi juga merupakan hal yang penting yang harus dimiliki siswa dalam proses pembelajaran guna menunjang keberhasilan proses pembelajaran di dalam kelas, namun pada kenyataannya kemampuan koneksi matematik ini belum dimiliki siswa. Hal ini terlihat pada penelitian Dalam penelitiannya, Ruspiani dan Yuniawati (dalam Mandur, 2013) menemukan bahwa kemampuan siswa untuk melakukan koneksi matematis tergolong masih rendah. Akibatnya prestasi belajar matematika siswa juga masih rendah. Jika siswa tidak memiliki kemampuan koneksi matematis, maka mereka lebih banyak mengingat dan mengulangi materi pelajaran, sehingga pembelajaran tidak akan berjalan dengan optimal. Dari uraian tersebut di atas, diperoleh kesimpulan yaitu perlunya suatu persepsi bahwa konsep-konsep matematika merupakan konsep-konsep yang saling berkaitan dan haruslah meresap dalam pembelajaran matematika di sekolah. Jika persepsi ini sebagai landasan guru dalam pembelajaran matematika, maka setiap mengkaji materi selalu mengaitkan dengan materi lain dan kehidupan sehari hari.

Hal di atas juga mendukung indikasi yang memandang bahwa pembelajaran matematika selama ini kurang melibatkan siswa secara aktif, pembelajaran matematika selama ini disampaikan kepada siswa secara informatif, artinya siswa hanya memperoleh informasi dari guru saja sehingga derajat "kemelekatannya" juga dapat dikatakan rendah. Dengan pembelajaran seperti ini, siswa sebagai subjek belajar kurang dilibatkan dalam menemukan konsep-konsep pelajaran yang harus dikuasainya. Hal ini menyebabkan konsep-konsep yang diberikan tidak membekas tajam dalam ingatan siswa sehingga siswa mudah lupa dan sering kebingungan dalam memecahkan suatu permasalahan yang berbeda 


\section{SEPREN: Journal of Mathematics Education and Applied}

Vol. 01, No.02, 16-27

mengurangi kecenderungan guru untuk mendominasi proses pembelajaran tersebut, sehingga ada perubahan dalam hal pembelajaran matematika yaitu pembelajaran yang berpusat pada guru sudah sewajarnya diubah menjadi berpusat pada siswa (Markaban, 2006).

Selain kemampuan koneksi matematik, kemampuan berpikir kreatif juga merupakan hal yang sangat penting yang harus dimiliki siswa, Mengembangkan kemampuan berpikir logis, analitis, sistematis, kritis maupun bekerja sama sudah lama menjadi fokus dan perhatian pendidik matematika di kelas. Tetapi, fokus dan perhatian pada upaya meningkatkan kemampuan berpikir kreatif dalam matematika jarang atau tidak pernah dikembangkan. Padahal kemampuan itu yang sangat diperlukan agar peserta didik dapat memiliki kemampuan memperoleh, mengelola, dan memanfaatkan informasi .

Kreativitas sering kali dianggap sebagai sesuatu keterampilan yang didasarkan pada bakat alam, di mana hanya mereka yang berbakat saja yang bisa menjadi kreatif. Anggapan ini tidak sepenuhnya benar, walaupun memang dalam kenyataannya terlihat bahwa orang - orang tertentu memiliki kemampuan untuk menciptakan ide-ide baru dengan cepat dan beragam. Namun demikian, sesungguhnya kemampuan berpikir kreatif pada dasarnya dimiliki semua orang.

Menurut Pehkonen (Fauziyah, 2013) mengemukakan bahwa "Berpikir kreatif dapat diartikan sebagai suatu kombinasi dari berpikir logis dan berpikir divergen yang didasarkan pada intuisi tetapi masih dalam kesadaran." Dalam berpikir kreatif, seseorang dituntut untuk dapat memperoleh lebih dari satu jawaban terhadap suatu persoalan dan untuk itu maka diperlukan imajinasi. Adapun berpikir analitis adalah berpikir yang sebaliknya menggunakan suatu pendekatan logis menuju ke jawaban tunggal.

Sebenarnya dalam menghadapi masalah kita membutuhkan kedua jenis berpikir tersebut, yaitu berpikir logis analitis dan berpikir kreatif. Berpikir logis-analitis sering disebut dengan berpikir konvergen, karena cara berpikir ini cenderung menyempit dan menuju ke jawaban tunggal. Sementara itu berpikir kreatif sering disebut sebagai berpikir divergen, karena di sini pikiran didorong untuk menyebar jauh dan meluas dalam mencari ide-ide baru.

Proses berpikir kreatif merupakan gambaran nyata dalam menjelaskan bagaimana kreativitas terjadi. Dalam berpikir kreatif proses yang terjadi ternyata melalui beberapa tahapan tertentu. (Fauziyah, 2013) Menyatakan proses berpikir kreatif dapat dilihat dari perspektif Teori Wallas. Wallas dalam bukunya "The Art of Thought" (New World Enclycopedia, Graham _Wallas.htm) menyatakan bahwa proses kreatif meliputi 4 tahap yaitu : Preparasi (mengumpulkan informasi yang relevan), Inkubasi (istirahat sebentar untuk mengendapkan masalah dan informasi yang diperoleh), Iluminasi (mendapat ilham), Verifikasi (menguji dan menilai gagasan yang diperoleh).

Kreativitas dalam matematika lebih pada kemampuan berpikir kreatif. Karena secara umum sebagian besar aktivitas yang dilakukan seseorang yang belajar matematika adalah berpikir. Beberapa ahli 


\section{SEPREN: Journal of Mathematics Education and Applied}

Vol. 01, No.02, 16-27

mengatakan bahwa berpikir kreatif dalam matematika merupakan kombinasi berpikir logis dan berpikir divergen yang didasarkan intuisi tetapi dalam kesadaran yang memperhatikan fleksibilitas, kefasihan dan kebaruan.

Pernyataan di atas membuktikan bahwa kemampuan berpikir kreatif juga tidak kalah pentingnya dimiliki siswa guna untuk menjadikan siswa memiliki kemampuan berpikir tingkat tinggi dalam setiap pemecahan masalah yang dihadapi siswa tersebut, namun pada kenyataaannya kemampuan berpikir kreatif ini belum dimiliki siswa Hal ini dapat terlihat berdasarkan hasil penelitian yang dilakukan (Azhari dan Somakim, 2013) bahwa kenyataan di lapangan menunjukkan bahwa kemampuan berpikir kreatif siswa belum optimal, rendahnya kemampuan siswa berpikir kreatif diduga karena selama ini guru tidak berusaha menggali pengetahuan dan pemahaman siswa sehingga kemampuan berpikir kreatif siswa sangat dangkal terhadap suatu masalah, kebanyakan siswa kurang memahami masalah. Selain itu rencana penyelesaian yang dilakukan siswa tidak terarah sehingga proses perhitungan belum memperlihatkan jawaban yang benar.

Tim Survey IMSTEP-JICA (Fachrurazi, 2011) di kota Bandung juga menemukan sejumlah kegiatan yang dianggap sulit oleh siswa untuk mempelajarinya dan oleh guru untuk mengajarkannya antara lain, pembuktian pemecahan masalah yang memerlukan penalaran matematis, menemukan, generalisasi atau konjektur, dan menemukan hubungan antara data-data atau fakta yang diberikan. Kegiatan-kegiatan yang dianggap sulit tersebut, kalau kita perhatikan merupakan kegiatan yang menuntut kemampuan koneksi dan berpikir tingkat tinggi. Dengan demikian dapat disimpulkan bahwa hasil survei tersebut menemukan bahwa siswa mengalami kesulitan jika dihadapkan kepada persoalan yang memerlukan kemampuan berpikir tingkat tinggi yang terkait dengan berpikir kreatif.

Semua kemampuan yang diharapkan dapat dimiliki oleh siswa tidak serta merta dapat terwujud hanya dengan mengandalkan proses pembelajaran yang selama ini terbiasa ada di sekolah kita, dengan urutan-urutan langkah seperti, diajarkan teori/definisi/teorema, diberikan contoh-contoh dan diberikan latihan soal. Proses belajar seperti ini tidak membuat anak didik berkembang dan memiliki kemampuan memahami serta mampu berpikir kreatif berdasarkan pemikirannya, tapi justru lebih menerima ilmu secara pasif. Dengan demikian, langkah - langkah dan proses pembelajaran yang selama ini umumnya dilakukan oleh para guru di sekolah adalah kurang tepat, karena justru akan membuat anak didik tidak mampu mengembangkan kemampuan yang dimilikinya. Dari kedua masalah di atas dapat disimpulkan bahwa kemampuan koneksi matematik dan kemampuan berpikir kreatif siswa masih rendah.

Pembelajaran matematika dengan siswa yang pasif memiliki kemungkinan besar mengalami kegagalan, dengan demikian untuk membawa ke arah pembelajaran yang dapat mengembangkan kemampuan koneksi matematik dan berpikir kreatif harus berangkat dari pembelajaran yang bersifat aktif, 


\section{SEPREN: Journal of Mathematics Education and Applied}

Vol. 01, No.02, 16-27

siswa diberi keleluasaan untuk mengkonstruksi potensi nya serta mengembangkan kemampuan matematika yang ia miliki, yang lebih banyak melibatkan diri nya aktif dalam proses berpikir.

Berkenaan dengan hal di atas, maka dengan memperhatikan berbagai konsep dan teori belajar dengan tujuan membawa implikasi kepada keharusan pembelajaran untuk menerapkan suatu model pembelajaran yang lebih memberdayakan siswa dengan meningkatkan produktivitas belajar untuk kebermaknaan konteks pembelajaran (Meaningful Learning) misalnya dengan menggunakan Discovery Learning.

Model pembelajaran ini pertama kali dikembangkan oleh Jerome Bruner, seorang ahli psikologi yang lahir di New York pada tahun 1915. Bruner menganggap bahwa belajar penemuan (Discovery Learning) sesuai dengan pencarian pengetahuan secara aktif oleh manusia dan dengan sendirinya memberikan hasil yang paling baik. Bruner menyarankan agar siswa hendaknya belajar melalui berpartisipasi aktif dengan konsep-konsep dan prinsip-prinsip agar mereka dianjurkan untuk memperoleh pengalaman dan melakukan eksperimen-eksperimen yang mengizinkan mereka untuk menemukan konsep dan prinsip itu sendiri. Belajar penemuan adalah proses belajar dimana guru harus menciptakan situasi belajar yang problematis, menstimulus siswa dengan pertanyaan-pertanyaan, mendorong siswa mencari jawaban sendiri, dan melakukan eksperimen. Belajar penemuan pada akhirnya dapat meningkatkan penalaran dan kemampuan untuk berpikir secara bebas dan melatih keterampilan kognitif siswa dengan cara menemukan dan memecahkan masalah yang ditemui dengan pengetahuan yang telah dimiliki dan menghasilkan pengetahuan yang benar-benar bermakna bagi dirinya. Adapun kelebihan dari Discovery Learning antara lain: (1) Hasilnya lebih berakar dari pada cara belajar yang lain. (2) Lebih mudah dan cepat ditangkap. (3) Dapat dimanfaatkan dalam bidang studi lain atau dalam kehidupan sehari-hari. (4) berdaya guna untuk meningkatkan kemampuan siswa menalar dengan baik.

Model pembelajaran ini dirancang dengan tujuan akhir yaitu meningkatkan kemampuan koneksi matematik dan berpikir kreatif siswa pada pelajaran matematika dan siswa merasa mampu dan berani dalam menyelesaikan setiap masalah yang dihadapinya serta yang terpenting siswa mempunyai rasa kepercayaan diri yang tinggi dalam setiap proses belajar mengajar berlangsung. Oleh karena itu, Discovery Learning ini dapat digunakan oleh para guru sebagai dasar melaksanakan kegiatan pembelajaran dengan baik dan sebagai suatu alternatif dalam usaha meningkatkan kemampuan koneksi matematik dan berpikir kreatif siswa guna tercapainya tujuan dari suatu proses pembelajaran yang diinginkan serta model pembelajaran ini juga dapat membuat proses pembelajaran matematika di kelas lebih menarik dan bermakna untuk dipelajari siswa.

\section{Metode Penelitian}


Penelitian ini merupakan penelitian eksperimen semu (quasi experiment) dengan tujuan untuk melihat apakah kemampuan koneksi matematik dan berpikir kreatif siswa menggunakan Discovery Learning berbeda dengan yang menggunakan Direct Instruction dan didalam pelaksanaan penelitian ini, menggunakan siswa kelompok eksperimen dan siswa kelompok kontrol. Pada kelompok eksperimen, peneliti memberikan perlakuan pembelajaran dengan menggunakan Discovery Learning, dan pada kelompok kontrol, peneliti memberikan perlakuan pembelajaran dengan menggunakan Direct Instruction. Dan didalam penelitian ini variabel yang diamati adalah kemampuan koneksi matematik dan berpikir kreatif siswa.

Populasi dalam penelitian ini adalah seluruh siswa kelas VII SMP Swasta Ampera Batang Kuis tahun pelajaran 2015/2016. Dari populasi penelitian dipilih kelas VII, selanjutnya dipilih 2 kelas dari 3 kelas secara random sebagai sampel penelitian. Dari siswa kelas VIII SMP Swasta Ampera Batang Kuis dengan cara acak terpilih kelas VIII-A dan kelas VIII-B dari 3 kelas yang ada. Kemudian dilakukan undian untuk memilih kelas eksperimen dan kelas kontrol. Dari hasil undian terpilih kelas VIII-A sebagai kelas eksperimen dan kelas VIII-B sebagai kelas kontrol. Kelas eksperimen adalah kelas yang diberi perlakuan menggunakan Discovery Learning, dan kelas kontrol diberi perlakuan menggunakan Direct Instruction. Data dianalisis secara deskriptif dan secara statistik inferensial. Yang dideskripsikan yaitu kemampuan awal, kemampuan koneksi matematik, kemampuan berpikir kreatif siswa, serta proses jawaban siswa. Selanjutnya dilakukan uji statistik inferensial (ANACOVA) untuk melihat apakah kemampuan koneksi matematik dan berpikir kreatif siswa menggunakan Discovery Learning berbeda dari Direct Instruction.

\section{Hasil Penelitian dan Pembahasan}

\section{a. Kemampuan Koneksi Matematik Siswa}

Kemampuan koneksi matematik siswa dapat diukur melalui kemampuan siswa mengoneksi antar topik matematik, mampu mengoneksi antar disiplin ilmu lain dan mampu mengoneksi dengan dunia nyata/kehidupan sehari-hari. Berdasarkan hasil penelitian, rata-rata skor kemampuan akhir koneksi matematik siswa yang diberi Discovery Learning sebesar 84,79 lebih tinggi dibandingkan dengan siswa yang diberi pembelajaran Direct Instruction sebesar 63,13. Hasil penelitian ini menunjukkan bahwa ratarata kemampuan akhir koneksi matematik siswa lebih tinggi menggunakan Discovery Learning dibandingkan dengan Direct Instruction. Kemudian dengan menggunakan analisis anakova menghasilkan kesimpulan bahwa terdapat perbedaan kemampuan koneksi matematik siswa yang diajarkan dengan Discovery Learning dengan Direct Instruction. Perbedaan ini dapat menjadi acuan pengambilan 


\section{SEPREN: Journal of Mathematics Education and Applied}

Vol. 01, No.02, 16-27

keputusan bahwa kemampuan koneksi matematik siswa menggunakan Discovery Learning lebih baik dibandingkan Direct Instruction.

Perbedaan hasil kemampuan koneksi matematik siswa di kedua kelas yaitu kelas eksperimen dan kelas kontrol pada indikator pertama yaitu mampu mengoneksi antar topik matematika, pada kelas eksperimen terlihat bahwa siswa yang diajarkan menggunakan Discovery Learning ketika diberikan soal mampu memberikan jawaban secara lengkap dan jelas dikarenakan siswa mengerti serta memahami prinsip - prinsip serta konsep-konsep matematika itu sendiri, dimana faktor "menemukan" ide baru siswa yang ketika PBM sudah dibiasakan. Sedangkan pada kelas yang diajarkan menggunakan Direct Instruction sebagian besar siswa kurang mampu mengaitkan prinsip -prinsip serta konsep-konsep matematika dalam setiap penyelesaian masalah, hal ini dikarenakan siswa tidak mampu mengkonstruk pengetahuan yang dia punya karena pembelajaran yang diterima monoton dan berpusat pada guru. Hal ini yang memungkinkan hasil kemampuan koneksi matematik siswa pada kelas Discovery Learning berbeda dengan kelas yang menggunakan Direct Instruction.

Pada indikator kedua yaitu mampu mengoneksi antar disiplin ilmu lain. Perbedaan di kedua kelas yaitu kelas eksperimen dan kelas kontrol adalah terlihat jelas pada kelas Discovery Learning memiliki karakteristik "menyelidiki" artinya siswa pada kelas ini bukan hanya sekedar bereksperimen dalam menyelesaikan masalah tetapi masalah yang ada kembali diselidiki apakah memiliki kaitan dengan disiplin ilmu lain, sehingga ketika proses itu terjadi maka siswa pada kelas ini mengetahui banyak hal tentang kaitan suatu masalah yang memiliki hubungan khusus dengan disiplin ilmu lain makan dari itu pada indikator yang kedua ini jelas siswa pada kelas Discovery Learning mampu menjawab masalah dengan baik dan benar karena modal awal pada saat PBM sudah ada sedangkan pada kelas Direct Instruction siswa hanya pasif sehingga memiliki kelemahan siswa hanya mampu menyelesaikan masalah ketika masalah yang mereka terima sama dengan masalah yang diberikan guru. Hal ini yang memungkinkan hasil kemampuan koneksi matematik siswa pada kelas Discovery Learning berbeda dengan kelas yang menggunakan Direct Instruction.

Pada indikator yang ketiga yaitu mampu mengoneksi dengan dunia nyata/kehidupan sehari-hari. Perbedaan terlihat ketika pada kelas Discovery Learning terbiasa diberikan untuk belajar mandiri dan mampu bekerja atas inisiatif sendiri sesuai dengan penerapannya di dalam kelas dimana juga guru selalu menghadapkan siswa dengan mengajukan pertanyaan terbuka atau guru memberikan pertanyaan yang merangsang siswa untuk mengaitkan ke kehidupan sehari-harinya sehingga siswa semangat dan terlibat aktif dalam PBM sehingga ketika siswa dihadapkan dengan masalah-masalah yang menuntut kemampuan nyatanya siswa akan dengan mudah memberikan jawaban yang baik dan benar serta implementasi dalam pengerjaan setiap penyelesaian masalah pun tepat . sedangkan pada kelas Direct Instruction komunikasi 
siswa hanya satu arah sehingga timbul model pembelajaran yang mengajak siswa hanya mendengarkan saja tanpa siswa ikut terlibat dalam ceramah guru tersebut, hal ini yang, mengindikasikan bahwa siswa pada kelas ini kurang mampu mengoneksi pengetahuannya dengan kehidupan nyatanya/sehari-harinya. Hal ini yang memungkinkan hasil kemampuan koneksi matematik siswa pada kelas Discovery Learning berbeda dengan kelas yang menggunakan Direct Instruction.

\section{b. Kemampuan Berpikir Kreatif Siswa}

Kemampuan berpikir kreatif siswa dapat diukur melalui kemampuan siswa berpikir lancar, berpikir luwes dan mampu berpikir orisinal (keaslian ide per masing-masing siswa). Berdasarkan hasil penelitian, rata-rata skor kemampuan akhir berpikir kreatif siswa yang diberi Discovery Learning sebesar 78,75 lebih tinggi dibandingkan dengan siswa yang diberi pembelajaran Direct Instruction sebesar 71,88. Hasil penelitian ini menunjukkan bahwa rata-rata kemampuan akhir berpikir rkeatif siswa lebih tinggi menggunakan Discovery Learning dibandingkan dengan Direct Instruction. Kemudian dengan menggunakan analisis anakova menghasilkan kesimpulan bahwa terdapat perbedaan kemampuan berpikir kreatif siswa yang diajarkan dengan Discovery Learning dengan Direct Instruction. Perbedaan ini dapat menjadi acuan pengambilan keputusan bahwa kemampuan berpikir kreatif siswa menggunakan Discovery Learning lebih baik dibandingkan Direct Instruction.

Perbedaan hasil kemampuan berpikir kreatif siswa di kedua kelas yaitu kelas eksperimen dan kelas kontrol pada indikator pertama yaitu mampu berpikir lancar, pada kelas eksperimen terlihat bahwa siswa yang diajarkan menggunakan Discovery Learning ketika diberikan soal mampu memberikan jawaban yang beragam, lengkap dan jelas dikarenakan siswa terbiasa diberi latihan secara rutin. Sedangkan pada kelas yang diajarkan menggunakan Direct Instruction sebagian besar siswa kurang mampu memberikan jawaban yang beragam, lengkap dan jelas hal ini dikarenakan siswa tidak mampu mengkonstruk pengetahuan yang dia punya karena pembelajaran yang diterima monoton dan berpusat pada guru. Hal ini yang memungkinkan hasil kemampuan berpikir kreatif siswa pada kelas Discovery Learning berbeda dengan kelas yang menggunakan Direct Instruction.

Pada indikator kedua yaitu berpikir luwes, artinya siswa mampu mengembangkan jawaban pribadinya dari soal yang dihadapkan padanya, lebih jelas ketika siswa dihadapkan dengan suatu masalah siswa harus mampu menyelesaikan masalah dengan berbagai caranya sendiri. Perbedaan di kedua kelas yaitu kelas eksperimen dan kelas kontrol adalah terlihat jelas pada kelas Discovery Learning memiliki karakteristik "menemukan" artinya siswa pada kelas ini bukan hanya sekedar menyelesaikan masalah tetapi siswa juga dituntut agar mampu menemukan idenya sendiri, sehingga ketika proses itu terjadi maka siswa pada kelas ini mengetahui banyak hal tentang temuan idenya tersebut maka dari itu pada indikator 
yang kedua ini jelas siswa pada kelas Discovery Learning mampu menjawab masalah dengan tidak terikat pada bunyi soal melainkan mampu mengembangkannya sedangkan pada kelas Direct Instruction siswa hanya pasif sehingga memiliki kelemahan siswa hanya mampu menyelesaikan masalah ketika masalah yang mereka terima sama dengan masalah yang diberikan guru. Hal ini yang memungkinkan hasil kemampuan berpikir kreatif siswa pada kelas Discovery Learning berbeda dengan kelas yang menggunakan Direct Instruction.

Pada indikator yang ketiga yaitu berpikir orisinal (ide asli siswa). Perbedaan terlihat ketika pada kelas Discovery Learning terbiasa diberikan untuk belajar menyelidiki, menemukan, mencoba hal baru, mengaplikasikan ilmu yang ada, adanya motivasi serta terciptanya variasi belajar yang memberikan stimulasi kepada siswa untuk lebih semangat dalam belajar sehingga dikarenakan tipe belajar seperti itu sudah diterima siswa maka ide asli dari siswa dapat diterapkan dalam setiap pemecahan masalah yang dihadapinya . sedangkan pada kelas Direct Instruction komunikasi siswa hanya satu arah sehingga timbul model pembelajaran yang mengajak siswa hanya mendengarkan saja tanpa siswa ikut terlibat dalam ceramah guru tersebut, hal ini yang, mengindikasikan bahwa siswa pada kelas ini kurang mampu mengkonstruk pengetahuan yang dia punya. Hal ini yang memungkinkan hasil kemampuan berpikir kreatif siswa pada kelas Discovery Learning berbeda dengan kelas yang menggunakan Direct Instruction.

\section{Kesimpulan}

Peneliti memperoleh kesimpulan sebagai berikut:

1. Kemampuan koneksi matematik siswa yang menggunakan Discovery Learning berbeda dari yang menggunakan Direct Instruction ini dilihat dari rata-rata siswa pada kelas yang menggunakan Discovery Learning yaitu 84,79 dengan 22 jumlah siswa yang tuntas sedangkan pada kelas Direct Instruction yaitu 63,13 dengan 10 jumlah siswa yang tuntas.

2. Kemampuan berpikir kreatif siswa yang menggunakan Discovery Learning berbeda dari yang menggunakan Direct Instruction ini dilihat dari rata-rata siswa pada kelas yang menggunakan Discovery Learning yaitu 78,75 dengan 20 jumlah siswa yang tuntas sedangkan pada kelas Direct Instruction yaitu 71,88 dengan 13 jumlah siswa yang tuntas.

3. Proses penyelesaian jawaban siswa yang menggunakan Discovery Learning lebih baik daripada yang menggunakan Direct Instruction.

4. Respon siswa positif menggunakan Discovery Learning.

\section{Referensi}


Azhari dan Somakim, (2013). Peningkatan Kemampuan Berpikir Kreatif Matematik Siswa Melalui Pendekatan Konstruktivisme Di Kelas VII Sekolah Menengah Pertama (SMP) Negeri 2 BanyuasinIII.[Online].Tersedia:http://ejournal.unsri.ac.id/index.php/jpm/article/download/992 1364. [20 September 2015].

Fachrurazi. (2011). Penerapan Pembelajaran Berbasis Masalah untuk Meningkatkan Kemampuan Berpikir Kritis dan Komunikasi Matematis Siswa Sekolah Dasar. [Online]. Tersedia : http://jurnal.upi.edu/file/8-Fachrurazi.pdf. [20 September 2015].

Fauziyah, I. N. L, dkk. (2013). Proses Berpikir Kreatif Siswa Kelas X dalam Memecahkan Masalah Geometri Berdasarkan Tahapan Wallas Ditinjau dari Adversity Quotient (AQ) Siswa. [Online]. Tersedia. http://jurnal.fkip.uns.ac.id/index.php/matematika/article/download/676/1083._[ 22 September 2015].

Kementerian Pendidikan dan Kebudayaan Republik Indonesia.(2013). Materi Pelatihan Guru : Implementasi Kurikulum 2013. (SMP/MTs: Matematika). Jakarta : Kementerian Pendidikan dan Kebudayaan Republik Indonesia.

Lestari, karunia eka. (2014). Implementasi Brain-Based Learning Untuk Meningkatkan Kemampuan Koneksi dan Kemampuan Berpikir Kritis Serta Motivasi Belajar Siswa SMP. [Online]Tersediahttp://digilib.unsika.ac.id/sites/default/files/File\%20JUDIKA/4.\%20Artikel\% 20Jurnal\%20(Karunia\%20Eka\%20Lestari_Matematika).pdf [ 22 September 2015]

Mandur, kanisius, dkk (2013). Kontribusi Kemampuan Koneksi, Kemampuan Representasi, dan Disposisi Matematis Terhadap Prestasi Belajar Matematika Siswa SMA Swasta di Kabupaten Manggarai.[Online]Tersedia:http://pasca.undiksha.ac.id/ejournal/index.php/JPM/article/downl oad/885/639 [ 23 September 2015]

Markaban. 2006. Model Pembelajaran Matematika dengan Pendekatan Penemuan Terbimbing. [Online].Tersediahttp://p4tkmatematika.org/downloads/ppp/PPP_Penemuanterbimbing.pdf[25 September 2015].

Trends in International Mathematics and Science Study (TIMSS). 2011. Average Mathematics Scores of Fourth-and Eight-grade Student by Country. http://timssandpirls.bc.edu/data-release2011/pdf/Overview-TIMSS-and-PIRLS-2011-Achievement.pdf. 